\title{
Application of a model to estimate total concentrations of dioxins and DL-PCBs in pork production in Chile ${ }^{\#}$
}

\author{
Aplicación de un modelo para estimar concentraciones totales de dioxinas y DL-PCBs \\ en producción de carne de cerdo en Chile
}

\author{
CE Valdovinos ${ }^{\mathrm{ac}^{*}}$, C Bustos-López ${ }^{\mathrm{b}}$, F Samsing ${ }^{\mathrm{a}}$, JT Schoffer ${ }^{\mathrm{a}}$ \\ ${ }^{a}$ Ecotoxicological Research Center, Faculty of Agricultural and Veterinary Sciences, Universidad Mayor, Santiago, Chile. \\ ${ }^{\mathrm{b}}$ Department of Basic Sciences, Faculty of Sciences, Universidad Santo Tomás, Santiago, Chile. \\ ${ }^{c} \mathrm{PhD}$ Program in Veterinary, Forestry and Agricultural Sciences, Universidad de Chile, Santiago, Chile.
}

\begin{abstract}
RESUMEN
En la presente investigación se desarrolló un modelo para estimar la concentración total o $C_{\text {Total }}$ de dioxinas (PCDD), furanos (PCDF) y bifenilos policlorados similares a dioxinas (DL-PCBs) en la carne de cerdo. El modelo fue aplicado considerando las categorías de materias primas o insumos que conforman dos dietas de referencia para la producción de cerdos en Chile. Muestras de dichas materias primas fueron analizadas para detectar la presencia de PCDD/Fs y DL-PCBs mediante el bioensayo EROD/H4IIE (determinación de la actividad de 7-etoxiresorufina- $O$-deetilasa en la línea celular de hepatoma de rata H4IIE). Los resultados obtenidos mediante el bioensayo fueron utilizados para modelar la acumulación a través de la ingesta, considerando diferentes porcentajes de absorción de estos contaminantes. En todos los casos considerados, se observó una disminución de $C_{\text {Total }}$ si el ciclo productivo se extendió hasta los 220 días. Se propuso la utilización de valores de riesgo para cada categoría de insumos incorporada en la dieta. Dichos valores se presentaron en 4 niveles según la concentración de PCDD/FS y DL-PCBs estimada en la carne de cerdo al momento de la faena. Los resultados de la modelación para ambas dietas, indicaron un nivel de riesgo muy alto para las materias primas de origen vegetal y mineral. Para los aceites vegetales y ácidos grasos de origen animal el nivel de riesgo fue alto, no obstante, las harinas de origen animal, los aglomerantes y antiaglutinantes, los productos lácteos y las premezclas presentaron un riesgo bajo.
\end{abstract}

Palabras clave: modelo de transferencia, dioxinas, riesgo, carne de cerdo.

\section{SUMMARY}

This research presents a model to estimate the total concentration or $C_{\text {Total }}$ of dioxins (PCDD), furans (PCDF) and dioxin-like polychlorinated biphenyls (DL-PCBs) in pork. The model was applied considering the categories of raw materials that make up two reference diets for pig production in Chile. Samples of such raw materials were analyzed to detect PCDD/Fs and DL-PCBs using the EROD-H4IIE bioassay (determination of 7-ethoxyresorufin- $O$-deethylase activity in the H4IIE rat hepatoma cell line). The results obtained from the bioassay were used to model dietary accumulation, considering different percentages of absorption of these contaminants. In all the cases considered, a decrease in $C_{\text {Total }}$ was observed if the production cycle was extended to 220 days. Risk values were proposed for each category of raw materials that compose the reference diets and these were classified into four levels according to the concentration of PCDD/Fs and DL-PCBs estimated in pork at the time of slaughter. The modeling results for both diets indicate a very high level of risk for vegetable and mineral components of the diet. A high level for vegetable oils and fatty acids of animal origin and a low risk level for animal meals, binders and anti-caking agents, dairy products and premixes.

Key words: transfer model, dioxins, risk, pork.

\section{INTRODUCTION}

It has been reported that food consumption accounts for approximately $90 \%$ of human exposure to dioxins (polychlorinated dibenzo-p-dioxins, PCDDs and dibenzofurans, PCDFs) (Bocio et al 2007), and pork meat is mentioned as one of the sources (Bernard et al 2002, Guruge et al 2005, Hoffman et al 2006, Hoogenboom et al 2007, Covaci et al 2008, Kim et al 2011). These findings

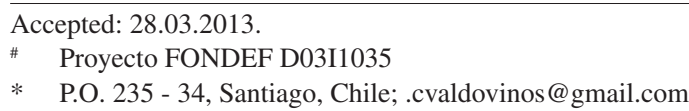

confirm that the accumulation of dioxins in fat tissue can occur at different levels of the food chain, and contaminated feedstuffs is one of the main ways of introducing dioxins into food for human consumption (Spiro and Stigliani 2004, Samsing et al 2011). In light of this, the European Union has adopted a series of regulatory measures to reduce the presence of PCDD/Fs and dioxin-like polychlorinated biphenyls (DL-PCBs) in food (including pork), through the establishment of action or threshold levels as a tool for authorities and operators to highlight those cases where it is appropriate to identify a source of contamination and to take measures for its reduction or elimination (EC 2006 ${ }^{\mathrm{a}}$, EC 2006 ${ }^{\mathrm{b}}$, EC 2011). 
On the other hand, several studies have been conducted to estimate concentrations of PCDD/Fs and DL-PCBs in poultry, beef and pork, based on exposure through dietary intake (Thorpe et al 2001, Hoogenboom et al 2004, Spitaler et al 2005, Guruge et al 2005, Traag et al 2006, van Eijkeren et al 2006, Brambilla et al 2008). Samsing et al (2011) have developed a model to estimate the individual contributions of the raw materials that are used in intensive pig farming in Chile as potential sources of contamination, taking into consideration dietary variations during breeding, raising and fattening. The present work is a continuation of said study, and formulates a new model that takes into consideration PCDD/Fs and DL-PCBs absorption by the adipose tissue of the pig at the moment of slaughter. The model can be used as a management tool by the producer since it identifies the levels risk of each raw material. If the concentration of dioxins in each of the feed components is known then the producers can calculate whether the pork being produced is likely to meet the requirements of national and international legislation.

\section{MATERIAL AND METHODS}

\section{ELABORATION OF DATABASES}

Samples of 35 vegetable raw materials, 34 vegetable oils, 56 mineral raw materials, 21 fatty acids of animal origin, 35 fatty acid mixtures, 28 animal meals, 14 fish meals, 10 binder and anti-caking agents, 7 dairy products and 39 premixes (multivitamins, aminoacids, antibiotics, others) were collected, considering raw materials that constitute the two reference diets (D1 and D2, table 1) applied to the pork production in Chile for local consumption and for export (Samsing et al 2011) The samples were analy- zed to detect the presence of PCDD/Fs and DL-PCBs by means of the EROD bioassay with H4IIE hepatoma cell lines of Rattus norvegicus (ATCC ${ }^{\circledR}, \mathrm{CRL}^{-1548^{\mathrm{TM}}}$ ), in the Ecotoxicological Research Center of the Universidad Mayor (CIEMAYOR). The modified protocol of Tillitt et al (1991) was used, as described by Schoffer et al (2011) and Samsing et al (2011), and incorporated into the standard procedure of the CIE Mayor P-TEC-001. The results of the analysis were expressed in pg TCDD-EQ/g of sample.

\section{STATISTICAL ANALYSIS}

A descriptive analysis of the dataset corresponding to the raw materials categories that comprise both diets was undertaken with the statistical software Minitab ${ }^{\circledR}$ version 15.0 for Windows (Minitab Inc., State College, PA, USA). Afterwards, a model for the transfer of dioxins to the final pork product was proposed.

\section{TRANSFER MODEL}

Fries (1996) developed a model to predict concentrations of lipophilic pollutants (e.g. dioxins) in growing pigs, given by the following equation:

$C_{t}=B_{t} / F_{t}$

Where $\mathrm{C}_{t}$ is the concentration of dioxins in the carcass fat in time $t, B_{t}$ is the body load of dioxins in time $t$ and $F_{t}$ is the quantity of body fat in time $t$. The uptake of these xenobiotics is considered a passive process and their elimination, according to Fries (1996) and Huwe (2006) is negligible throughout the pig's life. Hence, Huwe (2006) proposes:

Table 1. Reference diets used in pork production in Chile (D1 and D2), according to Samsing et al (2011). Dietas de referencia usadas en Chile en producción porcina (D1 y D2) según Samsing y col (2011).

\begin{tabular}{|c|c|c|c|c|c|c|c|}
\hline \multicolumn{2}{|c|}{ Raw materials } & \multicolumn{2}{|c|}{$\begin{array}{c}\text { Raising } \\
(21-70 \text { days })\end{array}$} & \multicolumn{2}{|c|}{$\begin{array}{c}\text { Breeding } \\
(71-120 \text { days })\end{array}$} & \multicolumn{2}{|c|}{$\begin{array}{c}\text { Fattening } \\
(121-180 \text { days })\end{array}$} \\
\hline \multicolumn{2}{|l|}{$(\%)$} & D1 & D2 & D1 & $\mathrm{D} 2$ & D1 & $\mathrm{D} 2$ \\
\hline \multicolumn{2}{|c|}{ Vegetable raw materials } & 61.17 & 61.17 & 92.02 & 91.05 & 92.74 & 91.05 \\
\hline \multicolumn{2}{|l|}{ Fish meal } & 10.50 & 10.50 & - & - & - & - \\
\hline \multicolumn{2}{|c|}{ Mineral raw materials } & 2.25 & 2.25 & 1.69 & 2.15 & 1.73 & 2.15 \\
\hline & Mixtures $^{(a)}$ & - & - & 3.50 & - & 2.75 & - \\
\hline \multirow[t]{2}{*}{ Fatty Acids } & Animal Origin & - & - & - & 2.10 & - & 2.10 \\
\hline & Vegetable oils & - & - & - & 4.05 & - & 4.05 \\
\hline \multicolumn{2}{|c|}{ Animal meals ${ }^{(b)}$} & - & - & 1.75 & - & 1.75 & - \\
\hline \multicolumn{2}{|c|}{ Binders and Anticaking agents } & - & - & 0.21 & - & 1.21 & - \\
\hline \multicolumn{2}{|c|}{ Dairy products } & 25.00 & 25.00 & - & - & - & - \\
\hline \multicolumn{2}{|l|}{ Premixes $^{(\mathrm{c})}$} & 1.08 & 1.08 & 0.83 & 0.65 & 0.82 & 0.65 \\
\hline
\end{tabular}

(a) Mixtures of fatty acids of animal origin, vegetable origin, and recycled oils (e.g. from fryers).

(b) Meat and bone meals, blood meals, feather meals, and other terrestrial animal by-products meals.

${ }^{(c)}$ Includes enzymes, multivitamins, amino acids, antibiotics, and other nutritional additives. 
$F_{t}=0.0028 \cdot t^{1.8173}$

Following this, Samsing et al (2011) proposed a multiplicative model to determine $B$, in which the body load of dioxin increases proportionally to the consumption of polluted food:

$B_{t}=A \cdot D \cdot R M \cdot I_{W} \cdot t$

In which $A$ is the absorption coefficient, $D$ is the percentage of the raw materials included in the diet, $R M$ is the average contamination of the raw materials, $I_{W}$ is the daily intake of food ad libitum and $t$ the days of exposure. $I_{W}$ depends on the body weight $(W)$ and is obtained from the following equation (Fries 1996):

$I_{W}=4.003\left(1-\mathrm{e}^{-0.01768 \cdot \mathrm{W}}\right)$

To calculate the body load in each stage $I_{W}$ is used (average of the intake at the beginning and ending of the stage), how to obtain $W$ (in $\mathrm{kg}$ ) is proposed by Huwe (2006):

$W=0.7716 \cdot t-2.9701$

Considering the previous models (Fries 1996, Huwe 2006 and Samsing et al 2011) the following model was developed to estimate the total concentration $\left(C_{\text {Total }}\right)$ of $\mathrm{PCDD} /$ Fs and DL-PCBs in pork:

$$
\left.C_{\text {Total }}\left(\begin{array}{l}
t, I, \\
J, A
\end{array}\right)=A \cdot\left(\begin{array}{l}
1429.6429 t^{-0.8173} \\
\left(1-1.0539 e^{-0.0136 t}\right.
\end{array}\right)\right) \sum_{i=1}^{I} \sum_{j=1}^{J} R M_{j} D_{i j}
$$

In which $A$ is the absorption percentage, $R M_{j}$ the pollution of the $j$-thraw material, $D_{i j}$ the inclusion percentage of the raw material $j$ into the diet $i$, after exposing the animals $t$ days to the different diets.

Several authors claim that dioxin absorption through diet is approximately 20\% (Iben et al 2003, Huwe 2006, Brambilla et al 2008); however, in the modeling, absorption percentages that fluctuate between 5 and $20 \%$ were used, in order to compare the different curves obtained through the simulation.

\section{RISK VALUES}

The present study proposes the use of probability based risk values for each category of raw materials that are incorporated into the diet, for producing pork that surpasses specific limits of PCDD/FS and DL-PCBs contamination. The values were determined considering Chilean (Ministerio de Salud Pública 2008) and European Union (EC 2006) regulations that include established intervention thresholds for pork (EC 2011). Therefore, risk values have 4 levels according to estimated concentrations of PCDD/FS and DL-PCBs in pork at the time of slaughter (180 days):
- Very high risk : 2 or more $\mathrm{pg} / \mathrm{g}$ of fat

- High risk : : $1.50-1.99 \mathrm{pg} / \mathrm{g}$ of fat

- Medium risk : $0.75-1.49 \mathrm{pg} / \mathrm{g}$ of fat (intervention threshold)

- Low risk $\quad: 0-0.74 \mathrm{pg} / \mathrm{g}$ of fat

Considering these risk values and after completing the simulating with all the categories of raw materials, the risk level of polluting pork with PCDD/Fs and DLPCBs was established for each raw material.

\section{RESULTS}

Diets D1 and D2 vary between themselves in the raw material percentage incorporated during breeding and fattening, while during raising the composition of the diet is the same. D2 has the same composition during breeding and fattening. D1 uses fatty acid mixtures as an energy source, while D2 includes animal fatty acids and vegetable oils (table 1 ).

Table 2 shows descriptive statistics of the results of the analysis of raw materials used in both diets. The highest mean contamination corresponds to mineral raw materials with $13.02 \mathrm{pg}$ TCDD-EQ/g (maximum value of $429.15 \mathrm{pg}$ TCDD-EQ/g), followed by fatty acid mixtures with $2 \mathrm{pg}$ TCDD-EQ/g of fat (maximum value of $17.62 \mathrm{pg}$ TCDD$\mathrm{EQ} / \mathrm{g}$ ), then fatty acids of animal origin with $1.46 \mathrm{pg}$ TCDD-EQ/g (maximum value of $12.95 \mathrm{pg} \mathrm{TCDD} / \mathrm{EQ} / \mathrm{g}$ ) and vegetable oils with $1.22 \mathrm{pg}$ TCDD-EQ/g (maximum value of $14.09 \mathrm{pg}$ TCDD-EQ/g). The lowest mean concentrations are found in premixes $(0.19 \mathrm{pg}$ TCDD-EQ/g) and dairy products $(0.35 \mathrm{pg}$ TCDD-EQ/g).

\section{RESULTS OF THE PROPOSED MODEL}

The simulation was done considering different dioxins absorption percentages $(5 \%, 10 \%, 15 \%, 20 \%)$, estimating $C_{\text {Total }}$ in the meat (in pg TCDD-EQ/g) at the end of each stage of the productive cycle for each of the diets: end of raising at 70 days, end of breeding at 120 days, end of fattening at 180 days and end of post-fattening at 220 days. Table 3 shows the estimated concentrations of PCDD/Fs and DL-PCBs in pork, for diets D1 and D2, considering the mean contamination of all the raw material categories that constitute the two diets. It is estimated that with $20 \%$ absorption dioxins concentration increases from $3.97 \mathrm{pg}$ TCDD-EQ/g at 70 days to 8.87 pg TCDD-EQ/g at the time of slaughter at 180 days. In contrast, if the slaughter were to occur at 220 days it is estimated that $C_{\text {Total }}$ decreases to $7.85 \mathrm{pg}$ TCDD-EQ/g. In the case of diet D2 with $20 \%$ absorption, it is estimated that $C_{\text {Total }}$ decreases from $3.97 \mathrm{pg}$ TCDD-EQ/g at 70 days to $3.18 \mathrm{pg}$ TCDD-EQ/g at 180 days and finally to $2.81 \mathrm{pg}$ TCDD-EQ/g at 220 days. Figure $1 \mathrm{~A}$ shows the results of the simulation with the different absorption percentages for D1, showing an abrupt increase in the estimated total 
CE VALDOVINOS ET AL

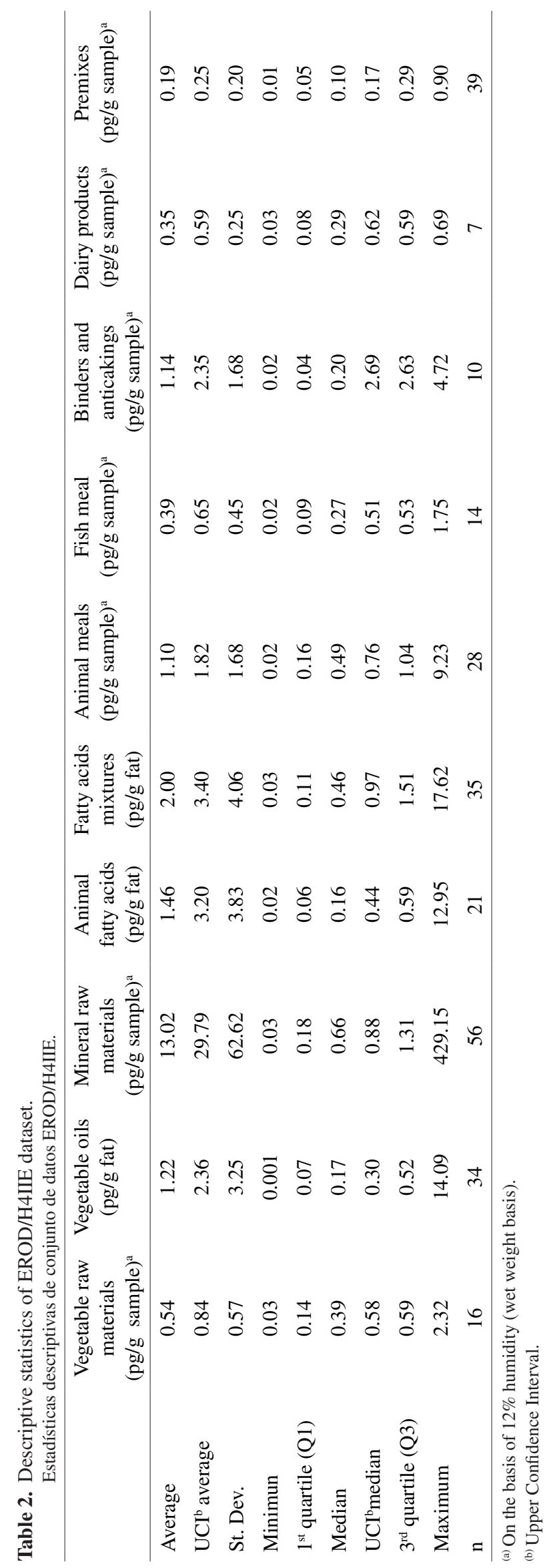


Table 3. Estimated concentrations of PCDD/FS and DL-PCBs in porks (pg/g of fat) for diets D1 and D2 after each stage of the production cycle, taking into consideration the average pollution of all raw materials categories comprising both diets and different absorption rates.

Concentraciones estimadas de PCDD/FS y DL-PCBs en carne de cerdo (pg/g de grasa) para las dietas D1 y D2 al finalizar cada etapa del ciclo productivo, considerando las medias de contaminación de todas las categorías de materias primas que conforman ambas dietas y con diferentes porcentajes de absorción.

\begin{tabular}{lccccccccc}
\hline Time (days) & $\mathrm{D} 1$ & $\mathrm{D} 2$ & $\mathrm{D} 1$ & $\mathrm{D} 2$ & $\mathrm{D} 1$ & $\mathrm{D} 2$ & $\mathrm{D} 1$ & $\mathrm{D} 2$ \\
$(5 \%)$ & $(5 \%)$ & $(10 \%)$ & $(10 \%)$ & $(15 \%)$ & $(15 \%)$ & $(20 \%)$ & $(20 \%)$ \\
\hline 70 & 0.99 & 0.99 & 1.98 & 1.98 & 2.98 & 2.98 & 3.97 & 3.97 \\
120 & 1.77 & 0.97 & 3.55 & 1.93 & 5.32 & 2.90 & 7.09 & 3.87 \\
180 & 2.22 & 0.80 & 4.44 & 1.59 & 6.65 & 2.39 & 8.87 & 3.18 \\
220 & 1.96 & 0.70 & 3.92 & 1.41 & 5.89 & 2.11 & 7.85 & 2.81 \\
\hline
\end{tabular}

A

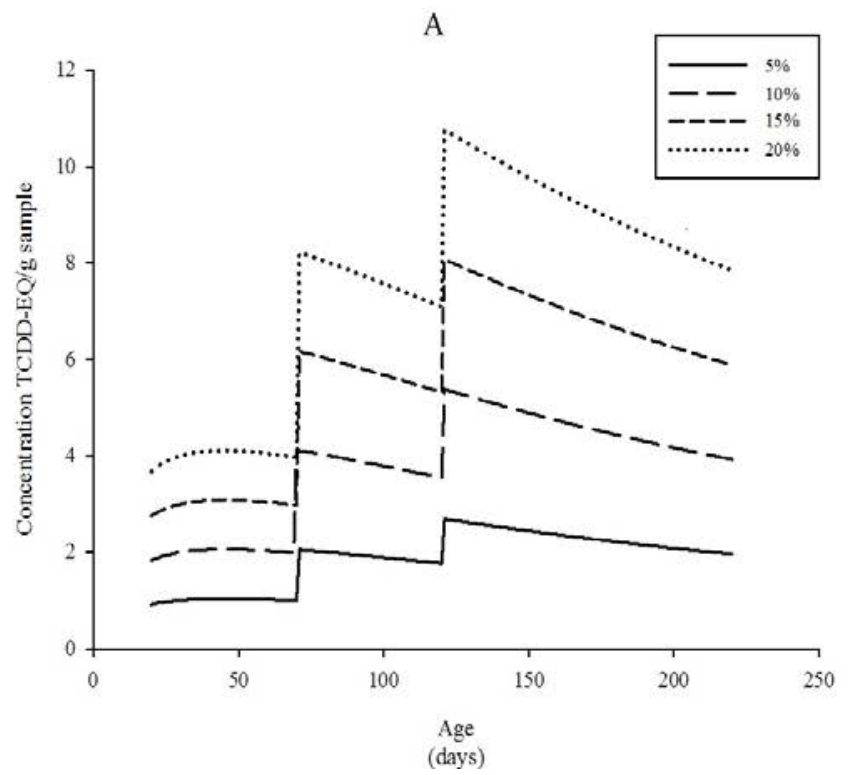

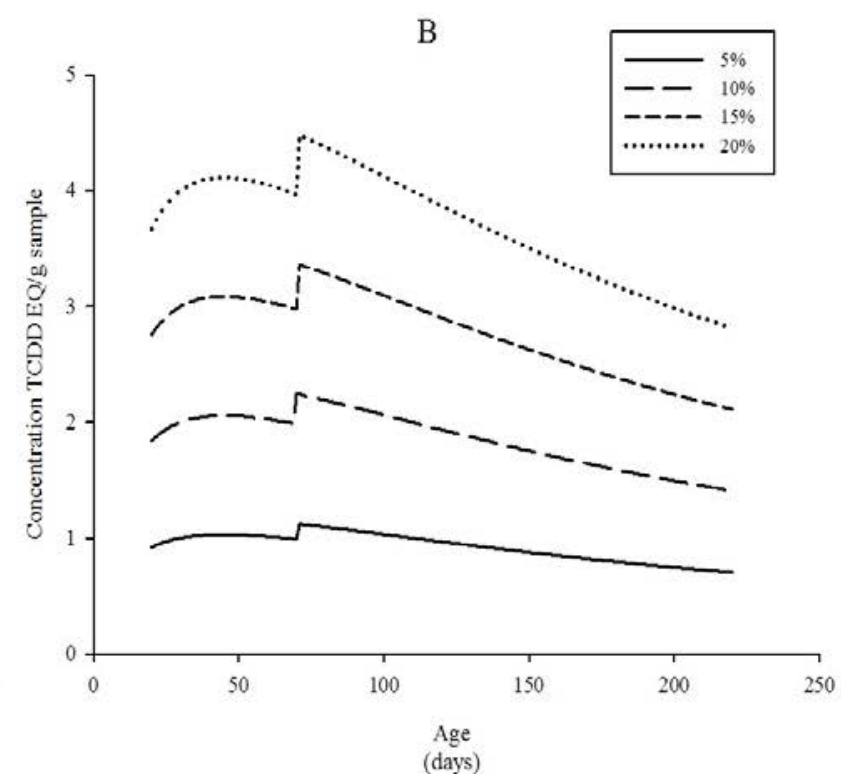

Figure 1. Estimated concentrations of PCDD/FS and DL-PCBs in pork, considering the average contamination of all raw materials used in D1 (A) and in D2 (B), with different absorption rates.

Concentraciones de PCDD/Fs y DL-PCBs estimadas en la carne de cerdo, considerando las medias de contaminación de todas las materias primas utilizadas en D1 (A) y en D2 (B), con diferentes porcentajes de absorción.

contamination at 71 days, then a decreasing tendency until the end of raising, to then reach a contamination peak at 121 days when the fattening period starts and finally it decreases until 220 days. With regards to D2 (figure 1B), it can be observed that the estimated total pollution is lower than in D1. A peak level of raw contamination is observed at 71 days and then decreases to 220 days.

The simulation was conducted separately with each raw material of average contamination while the rest of the raw materials that constitute the diet had a contamination equivalent to the first quartile (Q1); 20\% absorption and slaughter at 180 days was also considered. The results showed that the highest estimated $C_{\text {Total }}$ was obtained from vegetable raw materials $5.15 \mathrm{pg}$ TCDD$\mathrm{EQ} / \mathrm{g}$ for D1 y $5.10 \mathrm{pg}$ TCDD-EQ/g for D2 followed by mineral raw materials with 4.20 pg TCDD-EQ/g (D1) and $4.59 \mathrm{pg}$ TCDD-EQ/g (D2) while the lowest concentrations were estimated for animal meals, binder and anti-caking agents and premixes (0.45 pg TCDD-EQ/g for D1 and D2). If the slaughter occurs at 220 days, the estimated dioxin concentrations in pork decreases for all raw materials in both diets (figure 2).

Finally, the results of the simulation show that for D1 and D2, with means of $0.54 \mathrm{pg}$ TCDD-EQ/g for vegetable raw materials and $13.02 \mathrm{pg}$ TCDD-EQ/g for mineral raw materials, the level of risk is very high until 220 days. In vegetable oils and animal fatty acids of animal origin (1.22 and $1.46 \mathrm{pg}$ TCDD-EQ/g respectively) the level of risk is high until 220 days. Animal meals (1.1 pg TCDD-EQ/g), binder and anti-caking agents (1.14 pg TCDD-EQ/g), dairy products $(0.35 \mathrm{pg}$ TCDD-EQ/g) and premixes (0.19 pg TCDD-EQ/g) present a low level of risk (table 4). 

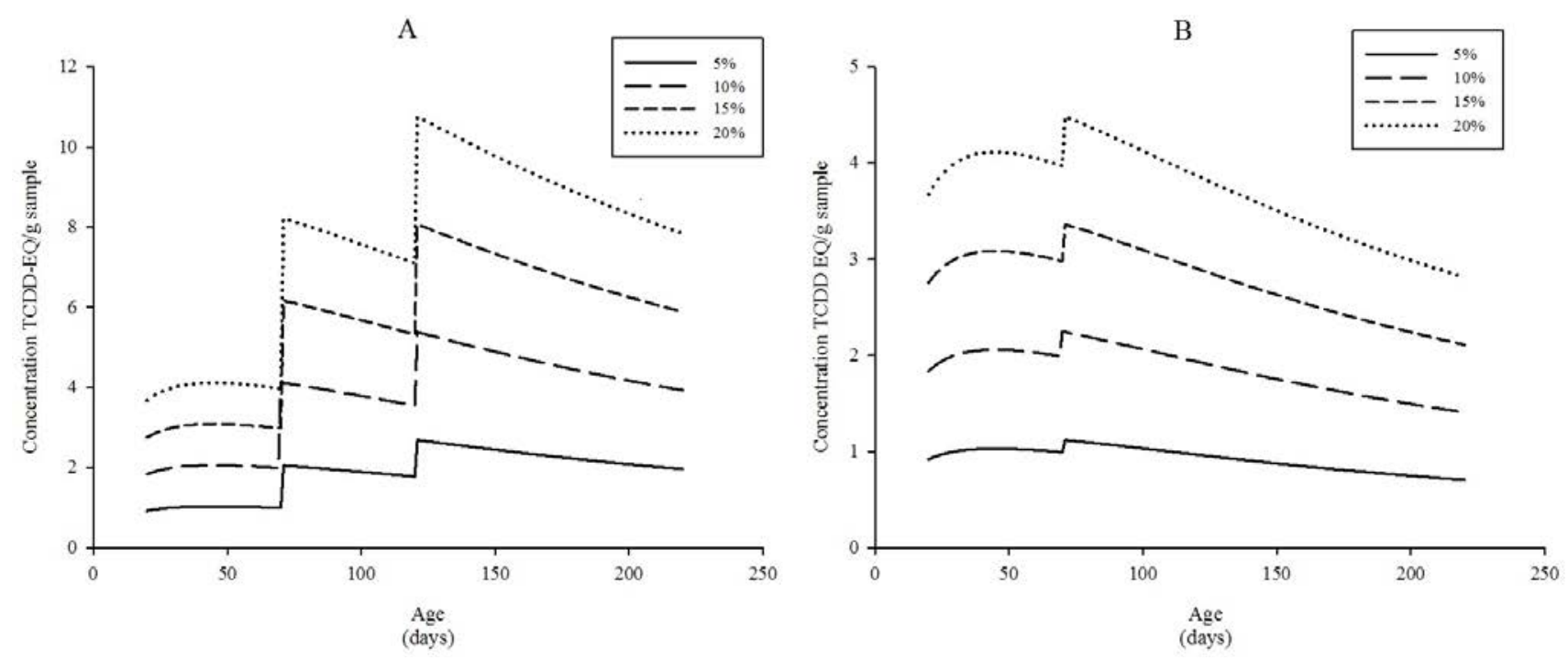

MPOV : Vegetable raw materials

MPOM : Mineral raw materials

AGM : Fatty acids mixtures

AA : Binder and anticakings

Figure 2. Estimated concentrations of PCDD/FS and DL-PCBs in pork for D1 (A) and D2 (B), if each raw material separately has average pollution and the others a contamination equivalent to Q1, considering $20 \%$ of absorption rate.

Concentraciones de PCDD/Fs y DL-PCBs estimadas en la carne de cerdo para D1 (A) y D2 (B), si cada materia prima por separado presenta contaminación media y las restantes una contaminación equivalente a Q1, considerando un porcentaje de absorción de $20 \%$.

Table 4. Risk levels for the sum of PCDD/Fs and DL-PCBs set for raw materials comprising D1and D2, if each of these raw materials separately has average pollution and the others pollution equivalent to Q1,with an absorption percentage of $20 \%$ and slaughtering at 180 and 220 days.

Niveles de riesgo para la suma de PCDD/Fs y DL-PCBs establecidos para las materias primas que conforman D1 y D2, si cada una de estas materias primas por separado, presenta contaminación media y las restantes una contaminación equivalente a Q1, con un porcentaje de absorción de $20 \%$ y beneficio a los 180 y 220 días.

\begin{tabular}{|c|c|c|c|c|c|c|c|c|c|c|}
\hline & $\begin{array}{l}\text { Vegetable } \\
\text { raw } \\
\text { materials } \\
\quad(\mathrm{pg} / \mathrm{g} \\
{\text { sample })^{\mathrm{a}}}\end{array}$ & $\begin{array}{l}\text { Vegetable } \\
\text { oils } \\
\text { (pg/g fat) }\end{array}$ & $\begin{array}{l}\text { Mineral } \\
\text { raw } \\
\text { materials } \\
\quad(\mathrm{pg} / \mathrm{g} \\
{\text { sample })^{\mathrm{a}}}\end{array}$ & $\begin{array}{l}\text { Animal } \\
\text { fatty } \\
\text { acids } \\
\text { (pg/g fat) }\end{array}$ & $\begin{array}{c}\text { Fatty acids } \\
\text { mixtures } \\
\text { (pg/g fat) }\end{array}$ & $\begin{array}{c}\text { Animal } \\
\text { meals } \\
(\mathrm{pg} / \mathrm{g} \\
\text { sample })^{\mathrm{a}}\end{array}$ & $\begin{array}{l}\text { Fish meal } \\
\quad(\mathrm{pg} / \mathrm{g} \\
\text { sample })^{\mathrm{a}}\end{array}$ & $\begin{array}{l}\text { Bindersand } \\
\text { anticakings } \\
\quad(\mathrm{pg} / \mathrm{g} \\
\text { sample })^{\mathrm{a}}\end{array}$ & $\begin{array}{l}\text { Dairy } \\
\text { products } \\
(\mathrm{pg} / \mathrm{g} \\
{\text { sample })^{\mathrm{a}}}^{\text {a }}\end{array}$ & $\begin{array}{l}\text { Premixes } \\
\quad(\mathrm{pg} / \mathrm{g} \\
\text { sample })^{\mathrm{a}}\end{array}$ \\
\hline Mean & 0.54 & 1.22 & 13.02 & 1.46 & 2.00 & 1.10 & 0.39 & 1.14 & 0.35 & 0.19 \\
\hline D1 (180) & VH & - & $\mathrm{VH}$ & - & $\mathrm{H}$ & $\mathrm{L}$ & $\mathrm{H}$ & $\mathrm{L}$ & $\mathrm{L}$ & $\mathrm{L}$ \\
\hline D2 (180) & $\mathrm{VH}$ & $\mathrm{H}$ & $\mathrm{VH}$ & $\mathrm{H}$ & - & - & $\mathrm{H}$ & - & $\mathrm{L}$ & $\mathrm{L}$ \\
\hline D1 (220) & $\mathrm{VH}$ & - & $\mathrm{VH}$ & - & $\mathrm{H}$ & $\mathrm{L}$ & M & $\mathrm{L}$ & $\mathrm{L}$ & $\mathrm{L}$ \\
\hline D2 (220) & $\mathrm{VH}$ & $\mathrm{H}$ & $\mathrm{VH}$ & M & - & - & M & - & $\mathrm{L}$ & $\mathrm{L}$ \\
\hline
\end{tabular}

(a) On the basis of $12 \%$ humidity (wet weight basis).

$\mathrm{VH}$ : Very high risk

$\mathrm{H}$ : High risk

M : Medium risk

L : Low risk

\section{DISCUSSION}

The present study was carried out using the ERODH4IIE bioassay on raw materials that constitute two reference diets for the production of pigs in Chile, to obtain the values of total equivalence (TEQ) of PCDD/Fs and DL-PCBs without identifying specific congeners.

The results of the simulation, considering the mean levels of contamination of all the raw material categories, show that D1 would generate higher levels of contamina- 
tion in meat than D2 for all percentages of PCDD/Fs and DL-PCBs absorption, due to the variation in the contents of the diets in the stages of breeding and fattening. In turn, an abrupt increase is observed with D1 on the total estimated contamination at 71 days, which is a consequence of ration change, and then a decrease is observed until the end of raising. Later, a new increase in contamination is reached at 121 days, when the fattening ration starts being used. Finally, the estimated contamination decreases until 220 days (figure 1A). With regards to D2 (figure 1B) a peak level of contamination is observed at the beginning of the breeding stage, then the level decreases steadily towards 220 days. This decreasing tendency agrees with the reports of Samsing et al (2011). Fernandes et al (2011) demonstrated a slight decrease in the TEQ values of pork when the age of the animal increased. Once the dioxins are absorbed by the organism, metabolization and excretion of these compounds is very low (Fries 1996, Hoogenboom et al 2004, Spitaler et al 2004), therefore, the reduction in dioxins concentration is caused by a dilution in the fat content of the animal, which increases as the animal grows (Fries 1995, Spitaler et al 2004, Hoogenboom 2004, Shen et al 2012).

Regarding the risk classifications and considering the results of the simulation shown in table 4 , both diets show a very high risk level, even up to 220 days, due to the high levels of raw materials of vegetable origin used for breeding and fattening (table 1). These results agree with the findings of Samsing et al (2011). Sources of dietary minerals also present a high risk level, considering that their average concentration exceeds the rest of the raw material categories that constitute D1 and D2 (table 2). Cases of dioxin contamination have been described due to the presence of contaminated zinc oxide in animal feed supplements (US FDA 2003, Kim et al 2011). Fatty acid mixtures in D1 and vegetable oils in D2 pose a high risk level. On the other hand, animal meals, binders and anti-caking agents, dairy products and premixes present a low risk level. Finally, the medium risk level proposed is incorporated in the classifications as a range of values (0.75-1 pg/g of fat) and represents an intervention threshold, which producers are advised to find, in order to reduce and eliminate the source of dietary contamination.

This model enables predictions for the total concentration of PCDD/Fs and DL/PCBs in pork, but it does not estimate the distribution of contaminants in the different fat deposits found in the carcass. Spitaler et al (2004) fed pigs with contaminated feedstuffs, and found important differences in the PCDD/Fs concentrations in the cuts of the belly, loin and fore-end. Further investigations are needed in order to estimate the distribution of contaminants, such as in vivo studies that keep the animals under observation until 220 days of age, with periodic measuring of PCDD/Fs and DL-PCBs in different carcass cuts, considering body fat distribution. Such studies should include sample analysis by high resolution gas chromatography coupled with high resolution mass spectrometry (HRGC/ HRMS) to identify PCDD/Fs and DL-PCBs congeners.

\section{ACKNOWLEDGEMENTS}

The authors would like to thank the Columbia Environmental Research Center (CERC) of the U.S. Geological Survey, in particular Dr. Donald Tillitt, Diane Nicks and Mike Tanner, as well as Dr. Pedro Cattan, Dr. Carla Delporte, Christopher Riley and the National Commission for Scientific and Technological Research (CONICYT).

\section{REFERENCES}

Bernard A, F Broeckaert, G De Poorter, A De Cock, C Hermans, C Saegerman, G Houins. 2002. The Belgian PCB/ dioxin incident: analysis of the food chain contamination and health risk evaluation. Environ Research Section A 88, 1-18.

Bocio A, JL Domingo, G Falcó, JM Llobet. 2007. Concentrations of PCDD/PCDFs and PCBs in fish and seafood from the Catalan (Spain) market: Estimated human intake. Environ Int 33, 170-175.

Brambilla G, AL Iamiceli, F Ferri, A di Domenico. 2008. Normative and pre-normative aspects for the management of actual and perspective POPs in meat and meat products. Meat Sci 78, 25-33.

Covaci A, S Voorspoels, P Schepens, P Jorens, R Blust, H Neels. 2008. The Belgian PCB/dioxin crisis- 8 years later. An overview. Environ Toxicol Pharmacol 25, 164-170.

EC, European Commission. 2006 ${ }^{\mathrm{a}}$. Commission Directive 2006/13/EC of 3 February 2006 amending Annexes I and II to Directive 2002/32/EC of the European Parliament and of the council on undesirable substances in animal feed as regards dioxins and dioxin-like PCBs. Official Journal of the European Union. L 32/44. 4.2.2006.

EC, European Commission. 2006 ${ }^{\mathrm{b}}$. Commission Regulation (EC) $\mathrm{N}^{\circ} 1883 / 2006$ of 19 December 2006 laying down methods of sampling and analysis for the official control of levels of dioxins and dioxin-like PCBs in certain foodstuffs. Official Journal of the European Union L 364/32. 20.12.2006.

EC, European Commission. 2011. Recommendations. Commission Recomendation of 23 August 2011 on the reduction of the presence of dioxins, furans and PCBs in feed and food. (2011/516/EU). Official Journal of the European Union. 24.8.2011. L 218/23.

FDA, Food and Drugs Administration. 2003. Information for manufacturers of animal feed mineral mixes. CVM Updated in March 12, 2003.

Fernandes AR, C Foxall, A Lovett, M Rose, A Dowding. 2011. The assimilation of dioxins and PCBs in conventionally reared farm animals: Occurrence and biotransfer factors. Chemosphere 83, 815-822.

Fries G. 1995. A review of the significance of animal food products as potential pathways of human exposure to dioxins. J Anim Sci 73, 1639-1650.

Fries G. 1996. A model to predict concentration of lipophilic chemicals in growing pigs. Chemosphere 32, 443-451.

Guruge KS, N Seike, N Yamanaka, S Miyazaki. 2005. Polychlo- 
rinated dibenzo-p-dioxins, -dibenzofurans, and biphenyls in domestic animal food stuff and their fat. Chemosphere 58, 883-889.

Hoffman MK, J Huwe, C Deyrup, M Lorentzsen, R Zaylskie, N Clinch, P Saunders, W Sutton. 2006. Statistically designed survey of polychlorinated dibenzo-p-dioxins, polychlorinated dibenzofurans and co-planar polychlorinated biphenyls in U.S. meat and poultry, 2002-2003: results, trends, and implications. Environ Sci Technol 40, 5340-5346.

Hoogenboom LAP, CA Kan, TFH Bovee, G van der Weg, C Onstenk, WA Traag. 2004. Residues of dioxins and PCBs in fat of growing pigs and broiler fed contaminated feed. Chemosphere 57, 32-42.

Hoogenboom LAP, JCH Van Eijkeren, MJ Zeilmaker, MJB Mengelers, R Herbes, J Immerzeel, WA Traag. 2007. A novel source for dioxins present in recycled fat from gelatin production. Chemosphere 68, 814-823.

Huwe J. 2006. Uptake of dioxin-like compounds in growing swine: correlation between experimental and predicted data. Organohalogen Compd 68, 197-200.

Iben C, J Böhm, H Tausch, J Leibetseder, W Luf. 2003. Dioxin residues in the edible tissue of broiler chicken. J Anim Physiol Anim Nutr 87, 142-148.

Kim M, D-G Kim, S-W Choi, P Guerrero, J Norambuena, G-S Chung. 2011. Formation of polychlorinated dibenzo-p-dioxins/dibenzofurans (PCDD/Fs) from a refinery process for zinc oxide used in feed additives: a source of dioxin contamination in Chilean pork. Chemosphere 82, 1225-1229.

MINSAL, Ministerio de Salud, Chile. 2008. Resolución Exenta $\mathrm{N}^{\circ} 499$ de 16 de agosto de 2008, Santiago, Chile.

Samsing F, C Bustos-López, JT Schoffer, CA Mattar, A González, C Robles, O Acevedo, CE Valdovinos. 2011. Insumos utilizados en la preparación de alimentos en producción porcina y su potencial de contaminación por dioxinas en la carne. Arch Med Vet 43, 287-294.

Shen H, B Henkelmann, WA Rambeck, R Mayer, U Wehr, KW Schramm. 2012. The predictive power of the elimination of dioxin like pollutants from pigs: An in vivo study. Environ Int 38, 73-78.

Schoffer JT, C Bustos-López, P Sotomayor, CA Mattar, A González, C Robles, F Samsing, O Acevedo, CE Valdovinos. 2011. Aplicación del bioensayo EROD-H4IIE para la determinación de dioxinas en carnes de pollos broiler: Un estudio de equivalencia con la cromatografía de gases de alta resolución acoplada a espectrometría de masas de alta resolución. Arch Med Vet 43, 259-266.

Spiro TG, M Stigliani. 2004. Sustancias químicas tóxicas. En: Spiro TG, Stigliani M (eds). Química Ambiental. $2^{\text {a }}$ Ed. Pearson Educación SA, Madrid, España, Pp 413-460.

Spitaler M, C Iben, H Tausch. 2005. Dioxin residues in the edible tissue of finishing pigs after dioxin feeding. J Anim Physiol Anim Nutr 89, 65-71.

Thorpe S, M Kelly, J Startin, N Harrison, M Rose. 2001. Concentration changes for $5 \mathrm{PCDD} / \mathrm{F}$ congeners after administration in beef cattle. Chemosphere 43, 869-879.

Tillitt DE, JP Giesy, GT Ankley. 1991. Characterization of the H4IIE rat hepatoma cell bioassay as a tool for assessing toxic potency of planar halogenated hydrocarbons in environmental samples. Environ Sci Technol 25, 87-92.

Traag WA, CA Kan, G van der Weg, C Onstenk, LAP Hoogenboom. 2006. Residues of dioxins(PCDD/Fs) and PCBs in eggs, fat and livers of laying hens following consumption of contaminated feed. Chemosphere 65, 1518-1525.

Van Eijkeren JCH, MJ Zeilmaker, CA Kan, WA Traag, LAP Hoogenboom. 2006. A toxicokinetic model for the carryover of dioxins and PCBs from feed and soil to eggs. Food Addit Contam 23, 509-517. 